\title{
MENYEMBUHKAN ATAU SEMAKIN MELUKAI: PERKEMBANGAN TEKNOLOGI TRANSPORTASI UMUM JALAN RAYA
}

\author{
Aan Aswari \\ Fakultas Hukum, Universitas Muslim Indonesia \\ aanaswari@umi.ac.id
}

\begin{abstract}
The collaboration of information technology with public transportation has had an impact on improving public services in the form of public transport online, due to the inability of the government to present an ideal form of service. This study illustrates that there is an expectation to be built by the concept of law, that through legal approach it can be used as a remedy to heal wounds from the assumption of failure arising from lack of law in accommodating the needs of the community in providing maximum service on road transport, while the emergence of regulations which gives the legality of an action, the reality actually makes an increasingly chronic wound, and in this paper does not reject the technology to collaborate with conventional products, but ideally these renewable products may fail to cope with human needs, but they should not coincide with the presence of renewable technology. The conclusion of the law should be easy to realize its goal of public transportation innovation and become a wound healer who did not recover from previous product failures.
\end{abstract}

Keywords: technology, transportation, online, street

\begin{abstract}
Abstrak
Kolaborasi teknologi informasi dengan alat transportasi umum telah memberikan dampak pada peningkatan pelayanan masyarakat dalam bentuk transportasi umum online, akibat ketidakmampuan pemerintah untuk menghadirkan sebuah bentuk pelayanan yang ideal. Kajian ini memberi gambaran bahwa terdapat sebuah harapan yang ingin dibangun oleh konsep hukum, bahwa sesungguhnya melalui pendekatan hukum maka dapat digunakan sebagai obat menyembuhkan luka dari anggapan kegagalan yang timbul akibat kekurangan hukum dalam mengakomodir kebutuhan masyarakat dalam memberikan pelayanan maksimal pada angkutan jalan, sedangkan timbulnya regulasi yang memberikan legalitas terhadap sebuah tindakan, realitasnya malah membuat sebuah luka yang semakin kronis, dan didalam tulisan ini tidak menolak teknologi untuk berkolaborasi dengan produk konvensional, akan tetapi idealnya produk terbarukan tersebut boleh saja mengalami kegagalan terhadap mengatasi kebutuhan manusia, namun seharusnya kegagalan tersebut tidak beriringan dengan hadirnya teknologi terbarukan. Kesimpulan hukum seharusnya mudah mewujudkan tujuannya pada inovasi transportasi umum dan menjadi pengobat luka yang lama tak sembuh dari kegagalan produk sebelumnya.
\end{abstract}

Kata kunci: teknologi, transportasi, online, jalanan

Introduction

Perkembangan teknologi terus memberikan manfaat bagi tumbuh kembangnya pemikiran-pemikiran baru, meski bagaikan pisau bermata dua dalam pemanfaatannya, ${ }^{1}$

\footnotetext{
Rahayu, Flourensia Sapty. Cyberbullying Sebagai Dampak Negatif Penggunaan Teknologi Informasi. Journal of Information Systems, 2012, 8.1: 22-31. Doi: Https://Doi.Org/10.21609/Jsi.V8i1.321
}

namun setiap sisinya dapat memberikan dorongan dalam bentuk memikirkan pengembangkan dan penanggulangan. Perbuatan hukum baru dalam masyarakat terus berkembang demi menggapai tujuannya yaitu mewujudkan kepentingannya dengan cara efektif dan efisien yang terkadang menimbulkan prilaku yang tidak berkesesuaian dengan regulasi yang ada. 
Pemanfaatan teknologi disegala aspek mulai diterapkan tanpa batas penerapannya, manusia saat ini terus mencoba berkarya untuk menemukan sebuah bentuk baru kegiatan yang biasanya dilakukan secara konvensional menjadi sebuah tindakan mengkolaborasikan kegiatan yang dapat pula diselesaikan dengan memanfaatkan teknologi sistem elektronik. Kini, alat transportasi umum masyarakat dari model angkutan kota, taksi, dan ojek konvensional berubah setelah mengkolaborasikannya dengan sistem elektronik, maka di Indonesia dikenal dengan Gojek, Grab, dan Uber. Sistem transportasi berbasis online ini telah digunakan oleh masyarakat perkotaan telah meyebar secara cepat diberbagai wilayah perkotaan diseluruh Indonesia.

Perusahaan transportasi dengan sentuhan teknologi mengubah modal usaha menjadi lebih minim namun lebih efektif. Kini berkat sentuhan teknologi membuat kepastian mendapatkan kendaraan umum menjadi lebih jelas dari segi waktu, ${ }^{2}$ ketersediaan, dan harga sesuai dengan keinginan masyarakat yang terakomodir akibat keluhan atau kesulitan masyarakat mendapatkan kendaraan umum. Fenomena ini menggambarkan bahwa situasi tersebut bagaikan memberi luka baru ternyata hadir didalam batang tubuh pemberlakuan transportasi umum kepada hukum yang mengaturnya, karena masih beriringan pada dampak dari ketertarikan masyarakat lebih memanfaatkan teknologi transportasi umum ini yang seringkali menimbulkan bentrok antara driver dan supir. ${ }^{3}$ Gambaran diatas lalu menimbulkan pertanyaan, apakah kemudahan yang disajikan oleh teknologi ini turut pula membuat semakin mudah manusia melakukan/menciptakan berbagai perbuatan melawan hukum baru masih saja eksis ditengah masyarakat?

Pengemudi angkutan transportasi konvensional memang diakui dalam kesehariannya acap kali melakukan pelanggaran dalam berlalu lintas, meski aturan hukum jelas tertuang dalam hukum positif namun masih kurang efektif keberlakuannya dijalan raya, dalam hal ini terlihat bahwa

2 Amajida, Fania Darma. Kreativitas Digital Dalam Masyarakat Risiko Perkotaan: Studi Tentang Ojek Online "Go-Jek" Di Jakarta. Informasi, 2014, 46.1: 115128. Http: / /Dx.Doi.Org/10.21831/Informasi.V46i1.9657

3 Driver Dan Supir Angkutan Umum Dalam Kajian Ini Adalah Pengemudi Kendaraan, Namun Driver Lebih Merujuk Kepada Supir Angkutan Umum Berbasis Aplikasi, Dan Supir Tetap Pada Makna Pengemudi Angkutan Umum Konvensional. substansi hukum masih belum mampu mandiri menyelesaikan permasalahan dijalan raya tanpa adanya sarana dan prasarana serta penegak hukumnya yang menegakkan supremasi hukum, olehnya sumber daya manusia melalui upaya pengetahuan masyarakat dengan pemanfaatan teknologi sistem elektronik sehingga masyarakat dapat dengan mudah menerima informasi dari segala penjuru dunia dalam membuktikan pemikiran suatu pernyataan yang terkemukakan, maka melahirkan teknologi transportasi umum yang dikombinasikan dengan sistem elektronik yang memaksa tatanan hukum untuk berkonvergensi sehingga tercapainya efisiensi, ${ }^{4}$ yang kemudian diharapkan mampu diadakan pengawasan dan penerapan reward and punishment secara langsung ketika supir telah berubah menjadi driver transportasi umum berbasis online tidak patuh terhadap hukum positif yang berlaku.

Apakah driver transportasi umum berbasis online kemudian mampu menjawab masalah yang acapkali terjadi dilakukan para supir transportasi umum konvensional? Rupanya benar adanya terjadi peningkatan perubahan prilaku driver dalam berlalu lintas dijalan raya serta mengutamakan keselamatan penumpang yang juga dilindungi asuransi yang tambahan yang disediakan, ${ }^{5}$ sebagai jaminan adanya hak asasi manusia untuk dilindungi. ${ }^{6}$ Namun, peningkatan tersebut tidaklah begitu signifikan disebabkan penumpang terkadang juga turut menyetujui prilaku melanggar hukum yang dilakukan oleh driver, misalnya melewati jalan yang tidak seharusnya untuk dilewati demi melaksanakan tertib berlalulintas. ${ }^{7}$ Olehnya, berdasarkan pengamatan empiris terhadap teknologi transportasi umum berbasis online ini belum juga efektif menjamin kepastian hukum diterapkan oleh driver dan pengguna/penumpang, luka lama yang terdapat dibatang tubuh kehadiran transportasi umum ditengah masyarakat belum dapat disembuhkan juga. Padahal driver melewati proses rekrutmen dengan menggunakan standar yang tinggi

\footnotetext{
4 Budhijanto, D. (2010). Hukum telekomunikasi, penyiaran, dan teknologi informasi: regulasi dan konvergensi. Refika Aditama, Bandung. Hal, 97.

5 Lihat Hak Korban Pada Undang-Undang Nomor 22 Tahun 2009 Tentang Lalu Lintas Dan Angkutan Jalan, Pasal 240.

6 Sari, Ratna Kumala, et al. Pertanggungjawaban Pidana Korporasi Gojek Atas Tindak Pidana Kecelakaan Lalu Lintas Oleh Pelaku Driver Ojek Online Di Yogyakarta. Skripsi, Universitas Islam Indonesia, Yogyakarta. 2018.

Doly, Denico. Penegakan Hukum Terhadap UndangUndang Nomor 22 Tahun 2009 Tentang Lalu Lintas Dan Angkutan Jalan: Tantangan Dan Prospek. Jurnal Kajian, (Pusat Pengkajian, Pengolahan Data Dan Informasi/P3di Sekretariat Jenderal Dpr Ri),2016, 20.3: 219-240.
} 
dibandingkan supir, tentunya mereka yang menjadi seorang driver dapat dikategorikan sebagai masyarakat informasi, ${ }^{8}$ dan begitu pula penggunanya karena juga sebagai pemanfaat teknologi informasi, namun apakah mereka betul-betul secara hakiki dapat dikategorikan masyarakat informasi, atau hanya demi kepentingannya tercapai secara instan lalu berupaya membuat kesepakatan tanpa menerapkan kausa yang halal yang dinyatakan dalam Pasal 1320 KUHPerdata.

Fenomena terus berkembang dengan pesat, kini driver telah berevolusi demi tercapainya harapan meraih keuntungan sebesar-besarnya dan mengabaikan hukum yang berlaku pun terus terjadi, evolusi driver telah mencapai pada tingkatan kloning, artinya seseorang dapat menjalankan kendaraan lebih dari satu kendaraan tanpa perlu berpindah tempat duduknya, penggunanya pun mengakomodir kepentingan driver demi meraup keuntungan finansial bersama, jika zaman dahulu kisah fiksi menyatakan bahwa menjaga lilin untuk mendapatkan uang dengan cara mencuri, kini zamannya adalah menjaga koneksi internet agar terus mendapatkan uang juga dengan onrechmatigheid, Fenomena ini memperlihatkan bahwa era teknologi masih saja membawa beragam masalah baru yang membuat hukum meredup, ${ }^{9}$ karena kriteria menjadi masyarakat informasi yang sesungguhnya belum tercapai dalam situasi perkembangan teknologi pada aspek transportasi umum.

Subyek dalam kisah fiksi dahulu kala ternyata hadir dalam transportasi umum berbasis online (peretas/agen elektronik) mulai marak dilakoni beberapa oknum diwilayah Kota yang menerapkan transportasi tersebut. ${ }^{10}$ Kejahatan ini dilakukan dengan cara menjalankan kewajiban fiktif untuk menuntut hak pembayaran. Penyalahgunaan keilmuan yang dimiliki pelaku atas penguasaan teknologi menjadi sebuah perbuatan melawan hukum baru diera kini, tentunya dapat diasumsikan bahwa sebuah hak tidaklah layak untuk didapatkan atas dasar kewajiban yang semu

8 Masyarakat informasi adalah masyarakat yang telah memiliki pendidikan dan/atau mempunyai kesadaran akan arti pentingnya informasi, lihat: Makarim, Edmon, et al. Pengantar Hukum Telematika. Raja Grafindo. Jakarta, 2005. hal.31

${ }^{9}$ Qamar, Nurul; Mustamin, Hikmawati; Aswari, Aan. Local Wisdom Culture Of Bugis-Makassar In Legal Perspective. Adri International Journal of Law And Social Science, 2017, 1.1: 35-41.

10 https://metro.sindonews.com/read/1278361/170/rauprp600-juta-dari-order-fiktif-tuyul-grab-dicokok-polisi1517410196 (diakses, 27 Februari 2018) dijalankan dengan penyalahgunaan program yang jahat dalam sistem elektronik, berdasarkan asas yang tidak membenarkan untuk meraih keuntungan diatas kerugian orang lain. ${ }^{11}$ (karena hak harus terus diperjuangkan melalui menjalankan kewajiban)

Terlepas dari regulasi Peraturan Menteri tentang Penyelenggaraan Angkutan Orang Dengan Kendaraan Bermotor Umum Tidak Dalam Trayek di Indonesia, yang diatur dalam PM 108 Tahun 2017, driver mestinya tetap mengikuti pedoman untuk menyelenggarakan kewajibannya, yaitu menyelenggarakan secara nyata perpindahan penumpang dan/atau barang sebagai tugasnya, ${ }^{12}$ tetapi kini telah menjadi komoditi bagi penyalah guna keilmuan dibidang teknologi informasi untuk meraih keuntungan pada kelemahan yang terdapat dalam sistem elektronik, melalui pemenuhan kewajiban yang semu agar mendapatkan hak yang nyata melalui reward pada driver, penyelenggara agen elektronik ${ }^{13}$ seharusnya bertanggung jawab atas kerugian yang diderita pihak lain akibat harapan ingin berusaha minim dengan hasil maksimal melalui kejahatan dalam sistem elektronik.

Teknologi transportasi umum menjadi online merupakan sebuah kesempatan bagi masyarakat untuk meningkatkan kualitas diri melalui pemenuhan kebutuhan perekonomian masyarakat, dan menyembuhkan luka dalam sistem transportasi umum yang selama ini bertahan hingga rupanya telah kronis, namun kesempatan ini dijadikan sebuah peluang komoditi baru yang bergeser dari tujuan awal yang ingin diciptakan oleh penyedia jasa dalam melayani kebutuhan masyarakat, sedangkan kesempatan ini diciptakan untuk bertindak sesuai dengan hukum yang menjadi pedoman berprilaku. Hukum mestinya memberi kemudahan bagi penyedia jasa melalui produk hukumnya sebagai upaya membuat keadaan yang dibutuhkan oleh masyarakat secara menyeluruh dapat dirasakan, krisis berprilaku ideal dalam berhukum (law in idea) ditengah masyarakat dalam pemanfaatan teknologi informasi ini menyebabkan hukum mengalami keredupan, dimana diharapkan teknologi hukum

\footnotetext{
11 Hadjon, P. M., \& Djatmiati, T. S. (2005). Argumentasi hukum. Penerbit Gajah Mada University Press, Yogyakarta. Hal, 29.

12 Denda Rp 500.000 jika melakukan pemesanan/menyelesaikan pemesanan sendiri, dan membuat akun penumpang untuk keperluan pemesanan baik dikerjakan sendiri maupun mitra. https://www.grab.com/id/kodeetik/ (diakses 3 Maret 2018)

13 Pasal 1 ayat (4) Peraturan pemerintah Republik Indonesia Nomor 82 tahun 2012 tentang Penyelenggaraan Sistem dan Transaksi Elektronik.
} 
harus secara dinamis mengikuti laju dinamika zaman.

Mengamati persoalan terhadap sentuhan teknologi dalam berbagai kebutuhan masyarakat dewasa ini, maka melalui kajian ini diharapkan mampu memberikan sebuah solusi melalui upaya menjawab permasalahan tentang potensi apa sajakah yang perlu diperhatikan agar mampu menyadari adanya luka baru dalam sistem transportasi umum berbasis online sebagai penyembuhan luka yang terbentuk dari kegagalan dalam memberikan pelayanan maksimal yang seharusnya dilakoni oleh produk transportasi umum, atau penyempurnaan keadaan melalui sentuhan teknologi sebagaimana harapan masyarakat dalam penyelenggaraan teknologi yang seharusnya terjadi?. Menjawab permasalahan tersebut dapat dijadikan rujukan agar dalam melegalkan tindakan yang timbul dari sebuah produk dengan sentuhan teknologi seharusnya mampu mengantisipasi potensi kegagalan seiring dengan lahirnya sebuah produk yang tersentuh dengan teknologi dimasa akan datang.

\section{Discussion}

A. Kehadiran Produk Inovatif yang Menyembuhkan.

Produk layanan yang lahir dari hasil sentuhan teknologi dalam kajian ini transportasi online yang diprakarsai oleh perusahaan aplikasi berbasis teknologi dibidang transportasi sebagaimana maksud dan tujuan yang dibangun dalam rangka mengakomodasi aksesibilitas bagi masyarakat. Sentuhan teknologi informasi memudahkan berbagai hal yang dulunya sulit untuk dimanfaatkan menjadi sebuah kemudahan bagi manusia dalam memanfaatkan banyak hal yang dibutuhkan dalam kegiatan kesehariannya. Keterkaitan manusia dengan kebutuhan yang dapat lebih memudahkan pencapaian tujuannya tersebut diprakarsai oleh sentuhan teknologi dalam sebuah produk yang dulunya sulit untuk dimanfaatkan, akibat sifat keterbatasan yang dirasakan tanpa peran sistem elektronik, ${ }^{14}$ sehingga melalui keterkaitan itulah memaksimalkan pemanfaatan produk.

Kehadiran sistem elektronik melebur pada setiap produk yang dapat dimanfaatkan oleh setiap orang merupakan harapan, sehingga kehadirannya telah meningkatkan efisiensi ${ }^{15}$ dalam pemanfaatan serta menutup kelemahan-kelemahan yang ada sebagai penyebab kegagalan pemanfaatan produk secara maksimal. Produk inovatif menyempurnakan banyak kebutuhan manusia ini dengan memberikan rasa kepuasan melalui konsep-konsep abstrak ide-ide hukum yang selalu berupaya untuk membuat keadaan selalu kondusif, ${ }^{16}$ sebagaimana masyarakat dapat lebih mudah memprediksi waktu kerja yang dibutuhkan dalam kegiatan kesehariannya ketika transportasi umum secara online memberikan informasi terkait estimasi waktu dalam pemanfaatannya.

Perwujudan pelayanan bagi

masyarakat melalui aturan yang dibentuk pemerintah kepada penyelenggara negara agar dalam pemanfaatannya dapat melahirkan bentuk keselamatan, yaitu sebuah keadaan yang diharapkan setiap orang dalam memanfaatkan kendaraan sebagai alat untuk memberikan baginya banyak waktu untuk kemudian ia dapat mempersiapkan/melakukan banyak hal ditengah proses perpindahan ketempat yang dituju, sehingga dapat meraih tujuan yang telah direncanakan. Keselamatan merupakan jaminan yang diberikan pemerintah kepada warganya yang terus ditingkatkan dengan teknologi keselamatan yang terus dibangun melalui produk hukum, dan disertai peran serta masyarakat dalam meningkatkan keamanan baik bagi dirinya sendiri maupun untuk orang

14 Pasal 1 ayat (1) Peraturan Pemerintah Nomor 82 Tahun 2012 tentang Penyelenggaraan Sistem dan Transaksi Elektronik.

15 Manueke, Manuela; Tampi, Gustaaf Budi; Londa, Very. Persepsi Masyarakat Tentang Jasa Transportasi Berbasis Aplikasi Online Di Kota Manado (Studi Kasus Di Pt. GoJek). Jurnal Administrasi Publik, 2018, 4.51.

16 Jazuli, Ahmad. Penegakan Hukum Penataan Ruang Dalam Rangka Mewujudkan Pembangunan Berkelanjutan. Jurnal Rechts Vinding: Media Pembinaan Hukum Nasional, 2017, 6.2: 263-282. 
banyak melalui penyediaan sarana yang memiliki teknologi tinggi dan/atau melalui upaya penciptaan keselamatan melalui sentuhan teknologi seperti halnya transportasi umum berbasis aplikasi.

Memperaman setiap warga negara merupakan bentuk perlindungan penyelenggara negara dengan perangkat hukum kepada rakyatnya dari berbagai ancaman yang juga terus berevolusi untuk tetap dapat memasuki celah yang ada pada sisi keadaan aman, lalu merusak sistem yang terbentuk dalam proses evolusi kondisi aman. ${ }^{17}$ Ancaman tersebut bertujuan untuk melemahkan sistem yang terbangun kearah yang lebih ideal, dan kembali membuat kegagalan sebuah produk dengan manjadikannya kembali sebuah luka yang sulit disembuhkan, mengingat sentuhan teknologi transportasi umum berbasis aplikasi terdiri dari serangkaian sistem yang rumit. ${ }^{18}$

Teknologi transportasi umum kini menawarkan bentuk kenyamanan bagi konsumen, ${ }^{19}$ yaitu sebuah peningkatan keadaan yang lebih melayani pengguna dan driver transportasi umum sehingga membentuk hal-hal yang dapat memfasilitasi segala kebutuhan bagi driver dan penumpangnya. Kini driver dan pengguna lebih bebas bereksplorasi dalam pemanfaatan transpotrasi umum dengan sentuhan teknologi melalui penyediaan segala fasilitas dan informasi yang terdapat pada driver, penumpang dan kendaraan yang digunakan sebagai alat transportasi

17 Hukum hadir untuk manusia dalam pemenuhan kebutuhan yang secara naluriah menginginkan kehidupan yang nyaman dalam suasana tenang dan tertib. Lihat: Maulidi, Maulidi. Paradigma Progresif dan Maqashid Syariah: Manhaj Baru Menemukan Hukum Responsif. Asy-Syir'ah Jurnal Ilmu Syari'ah dan Hukum, 2015, 49.2: 251-264. DOI: http://dx.doi.org/10.14421/asy-syir'ah.2015.\%25x

18 Smartphone bagian dari sistem tersebut, lihat: Aswari, Aan, et al. Legal Security On Cellphone Trading Through Electronic Media In Indonesia. Jurnal Dinamika Hukum, 2017, 17.2: 181-187. Doi: 10.20884/1.jdh.2017.17.2.800

Anindhita, Wiratri, Melisa Arisanty, And Devie Rahmawati. "Analisis Penerapan Teknologi Komunikasi Tepat Guna Pada Bisnis Transportasi Ojek Online (Studi Pada Bisnis Gojek Dan Grab Bike Dalam Penggunaan Teknologi Komuniasi Tepat Guna Untuk Mengembangkan Bisnis Transportasi)." Prosiding Seminar Nasional Indocompac. 2016. tersebut, misalnya komunikasi dapat terjalin secara intens untuk memenuhi kebutuhan masing-masing, baik driver maupun penumpang, yaitu solusi dalam menghindari kemacetan yang dapat mempersingkat waktu, titik lokasi pertemuan/pengantaran yang lebih mudah ditemukan, privasi dan keamanan meningkat, ketersediaan asuransi tambahan, bahkan bagi driver dapat menjalankan aktivitas lain tanpa harus dibatasi oleh waktu kerja (fleksibel), ${ }^{20}$ dan pola inovasi driver dalam meningkatkan pelayanan bagi pengguna, serta keunggulan lain yang tidak dapat ditemukan dalam transportasi umum secara konvensional, tentu gambaran ini dapat mejadi perwujudan dari cita-cita yang ingin digapai oleh seluruh pihak yang terlibat dalam pelaksanaannya serta membantu pemerintah dalam melayani kebutuhhan dasar masyarakatnya.

Ketertiban berkendara dalam rangka perwujudan tujuan yang ingin digapai oleh pemerintah dalam menjamin rasa aman warganya menjadi terwujud dengan adanya inovasi dibidang transportasi umum, rupanya perkembangan teknologi informasi yang dimanfaatkan oleh seluruh lapisan masyarakat di indonesia memberikan bantuan pemerintah, bahkan secara global dalam memperlancar segala urusan untuk mewujudkan kesejahteraan rakyat. Ketertiban meningkat akibat sistem elektronik mampu memberikan saran dalam bentuk informasi kepada penggunanya agar pengguna tersebut dapat memutuskan tindakan yang diperlukan dalam mengantisipasi masalah yang dapat timbul di waktu akan datang. Sebagai contoh, kecepatan kendaraan dan perpindahan titik penjemputan hingga titik tujuan dapat diprediksi melalui sistem elektronik yang memberikan informasi kepada penyelenggara transportasi umum online, driver dan penumpang hampir akurat dengan adanya sistem informasi kondisi traffic

20 Bakar, Noor Rahamah Haji Abu, et al. Masa Kerja Fleksibel dalam Sektor Formal di Bandar: Mengimbangi Kerjaya dan Tanggungjawab Keluarga (Flexible Working Hours in the Urban Formal Sector: Balancing Career and Family Responsibilities). Akademika, Universiti Kebangsaan Malaysia, 2013, 83.1. 
yang mempengaruhi batas maksimal kecepatan kendaraan. Ketertiban lahir dari hadirnya informasi kepada seluruh pihak yang membutuhkan dalam proses perpindahan tempat yang diselenggarakan oleh model transportasi umum yang inovatif, sehingga solusi terhadap kelancaran dalam perjalanan (kurang hambatan) menjadi teratasi sebagai output dari peran sentuhan teknologi yang menjangkau hingga pada transportasi umum.

Mengamati persoalan terjangkau tentu dapat dilihat dari berbagai aspek, terjangkau boleh jadi dimaksudkan harga dan juga kemampuan jangkauan transportasi umum dalam melayani kebutuhan masyarakat. Jika ditinjau dari sudut pandang harga, lagi-lagi informasi dalam penerapan pada transportasi umum inovatif ini memberikan gambaran nyata tentang harga yang disanggupi oleh calon pengguna, artinya kesepakatan terlebih dahulu terjadi sebelum memberikan sesuatu, melakukan sesuatu, dan/atau tidak melakukan sesuatu, ${ }^{21}$ tentunya potensi terjadinya kesepakatan berulang atau masalah perikatan dapat terelakkan sejak awal. Beda halnya dengan sistem transportasi umum sebelumnya, dimana jangkauan terbatas (dalam trayek) ${ }^{22}$ dan harga yang ditentukan mengabaikan jarak jangkauan, misalnya pada argo taksi yang terpengaruh dengan waktu tempuh, atau mikrolet yang jauh dekat bayarannya tetap sama, serta ojek konvensional yang memiliki kerelatifitasan harga yang cukup tinggi.

Produk inovasi dalam transportasi ini telah membuat masyarakat lebih merasakan kepastian hukum, artinya masyarakat lebih didekatkan dengan kepastian hukum sebagaimana salah satu tujuan yang ingin digapai dari konsep yang telah dibangun oleh hukum. Diawali dengan perkembangan alat bukti kini merambah ke perangkat-perangkat yang digunakan manusia dalam

21 Lihat Pasal 1234 Kitab Undang-Undang Hukum perdata Buku III tentang Perikatan

22 Lihat Pasal 140 dan Pasal 143 Undang-Undang Nomor 22 Tahun 2009 tentang Lalu Lintas dan Angkutan jalan memenuhi kebutuhan kesehariannya, dimana paradigma terkait alat bukti elektronik telah dapat dijadikan sebuah alat bukti yang dapat diterima oleh penegak hukum ${ }^{23}$ serta masyarakat dalam kesehariannya dalam melakukan hubungan kontraktual. Bukti-bukti tersebut berada dalam rekam jejak yang terhimpun dalam data-data elektronik sehingga dapat dijadikan acuan untuk menetapkan sebuah pertanggungjawaban terhadap kesalahan yang diakomodir oleh salah satu pihak pada sebuah perikatan yang dibangun.

Kepastian hukum itu dapat diwujudkan melalui mudahnya menelusuri data-data yang terdapat pada pusat data untuk membuktikan sebuah kebenaran pada sengketa perselisihan antara penumpang, driver dan penyedia jasa, sehingga penerapan sanksi akibat kesalahan tersebut dapat dilaksanakan sebagaimana cerminan kepastian hukum itu. Terkait dalam penerapan saksi pada transportasi umum berbasis aplikasi ini tentu diprakarsai oleh sumber data yang diperoleh dari informasi elektronik ${ }^{24}$ yang cenderung dapat dinilai memberikan informasi secara objektif, dibanding informasi para pihak terkait penyelesaian sengketa yang terjadi dalam pemanfaatan inovasi transportasi umum dengan sentuhan teknologi informasi.

Legalitas yang diberikan oleh hukum terhadap pelaksanaan produk hasil sentuhan dengan teknologi pada transportasi umum mengangkat citra $^{25}$ pekerjaan dan membuka lowongan pekerjaan yang besar untuk menurunkan angka pengangguran ${ }^{26}$ sebagaimana

23 Computers Are Universally Used And Accepted, Have Become Part of Everyday Life And Work And Are Presumed Realiable, Lihat: Asnawi, M. N. (2013). Hukum Pembuktian Perkara Perdata Di Indonesia. UII Press, Yogyakarta, hal, 100-101

24 Lihat Pasal 1 angka 1 Undang-Undang Nomor 19 Tahun 2016, Perubahan atas Undang-Undang Nomor 11 Tahun 2008 tentang Informasi dan Transaksi Elektronik

25 Aswari, Aan; Buana, Andika Prawira; Rezah, Farah Syah. Harmonisasi Hukum Hak untuk Dilupakan bagi Koran Digital terhadap Calon Mahasiswa di Makassar. Kanun: Jurnal Ilmu Hukum, Universitas Syiah Kuala, Banda Aceh. 2018, 20.1: 39-62. Doi: 10.24815/kanun.v20i1.9828

26 Pratama, Geistiar Yoga, Et Al. Perlindungan Hukum Terhadap Data Pribadi Pengguna Jasa Transportasi Online Dari Tindakan Penyalahgunaan Pihak Penyedia Jasa Berdasarkan Undang-Undang Nomor 8 Tahun 1999 Tentang Perlindungan Konsumen. Diponegoro Law Journal, 2016, 5.3: 1-19. 
harapan pemerintah selama ini. Citra sebuah kerjaan beranjak dari dasar dan memiliki penilaian yang masih rendah dimata masyarakat, untuk menaikkannya maka diperlukan berbagai upaya dalam rangka meraih peminat/pengguna melalui berbagai program yang dijalankannya agar dapat dinyatakan berharga, sebab sesuatu yang berharga cenderung memiliki nilai yang tinggi dan sebaliknya sesuatu yang bernilai tinggi belum tentu berharga. ${ }^{27}$ Seperti halnya kerjaan yang dulunya memiliki citra yang cukup rendah dimata masyarakat yaitu ojek, namun kini dengan sentuhan teknologi informasi yang dipadukan maka menjadi sebuah peluang kerjaan yang kini ramai yang memanfaatkannya dari berbagai lapisan masyarakat dengan memanfaatkan waktu luangnya untuk mendapatkan sejumlah keuntungan finansial, terlihat dari mereka yang memanfaatkan dari berbagai lapisan masyarakat tersebut maka membuat sebuah bentuk kesetaraan nilai pekerjaan yang dianggap masyarakat memiliki kualitas yang sama dengan pekerjaan yang dulunya dianggap memiliki gengsi, meskipun sebagian orang masih menganggap rendahnya citra yang terbentuk dari pekerjaan ini, namun hal itu masih terkesan ambigu karena dalam era informasi digital banyak ditemukan bentuk kepribadian ganda. ${ }^{28}$

Hukum hadir dan mengakomodir segala kepentingan masyarakat dalam hal ini transportasi umum berbasis aplikasi serta menampung perkembangan kebutuhan masyarakat dalam penyelenggaraan transportasi online, sehingga terlihat berbagai kemudahan yang ditawarkan dari teoknologi ini. Kemudahankemudahan ini membuat banyak masyarakat yang telah memutuskan untuk memanfaatkannya telah merasa hal ini merupakan sebuah kebutuhan masyarakat yang terakomodir secara maksimal untuk saat ini, sehingga

${ }^{27}$ Nurul Qamar, Dkk, 2018. Menguak Nilai Kearifan Lokal Bugis Makassar, Perspektif Hukum Dan Pemerintahan. Cv.Social Politic Genius (Sign), Makassar.Hal, 16

${ }^{28}$ Fidiyani, Rini, Dewi Sulistianingsih, and Pujiono Pujiono. "Law and Ethics of Communication in Social Media." Jurnal Dinamika Hukum 17.3 (2017): 258-265. hukum dalam aturan-aturan yang terbentuk untuk melegalkan kegiatan ini dan menjadi pengobat luka yang timbul dari kelemahan-kelemahan yang ada sebelumnya pada transportasi umum konvensional. Hal-hal yang dikemukakan diatas dapat terlihat dari gambaran diagram dibawah ini sehingga memperlihatkan adanya rasaya masyarakat yang terakomodir dalam sebuah produk terbarukan.

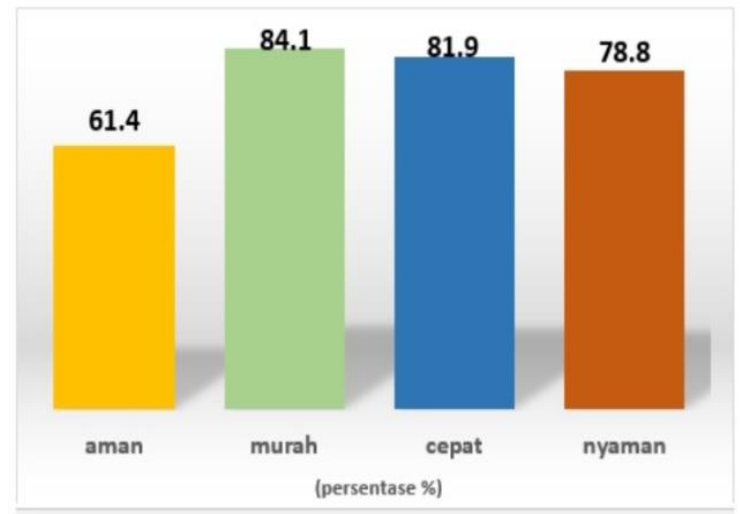

Diagram 1.29 Alasan Konsumen Memilih Transportasi Online.

Hukum mendorong upaya dalam mewujudkan semuanya dapat memberikan perlindungan dan penegakan hukum bagi masyarakat sehingga produk inovatif ini merupakan upaya menstimulus produk hukum yang mendukung penyelenggaraan model transportasi umum yang mengakomodir segala keinginan masyarakat yang sesuai dengan zaman, ${ }^{30}$ dan hal ini menjadi obat yang diharapkan oleh masyarakat sebagai penyembuhan luka akibat kegagalan hukum dalam merekayasa manusia untuk menjadi manusia-manusia yang mengalami peningkatan kualitas dengan membangun produk-produk dan hukum-hukum berkualitas pula.

B. Ketidaksiapan Hukum dalam Produk Inovatif Mempertahankan Luka

Lahirnya jasa transportasi umum berbasis aplikasi merupakan bentuk respon dari ketidakmampuan pemerintah dalam upayanya untuk transportasi-online-kawan-atau-lawan/ (Diakses 14 Maret 2018)

30 Sesuai dengan Pasal 4 tentang Hak Konsumen pada Undang-Undang Nomor 8 Tahun 1999 tentang Perlindungan Konsumen, lihat: Nitisusastro, M. (2012). Perilaku Konsumen dalam Perspektif Kewirausahaan. Bandung: Alfabeta. Hal, 259 
menghadirkan sebuah bentuk transportasi umum yang layak, dampaknya di Indonesia terdapat beberapa perusahaan jasa yang membuka layanan kepada masyarakat dalam menghadirkan impian masyarakat dalam bentuk transportasi umum berbasis aplikasi, seperti gambaran persepsi konsumen terhadap layanan transportasi dibawah ini, namun kehadirannya justru membuat masalah baru yang beriringan dengan sebuah produk inovatif yang sebelumnya diharapkan dapat menyelesaikan masalah kebutuhan masyarakat yang tidak terakomodir, dan benar-benar dapat mengobati luka lama untuk sementara waktu.

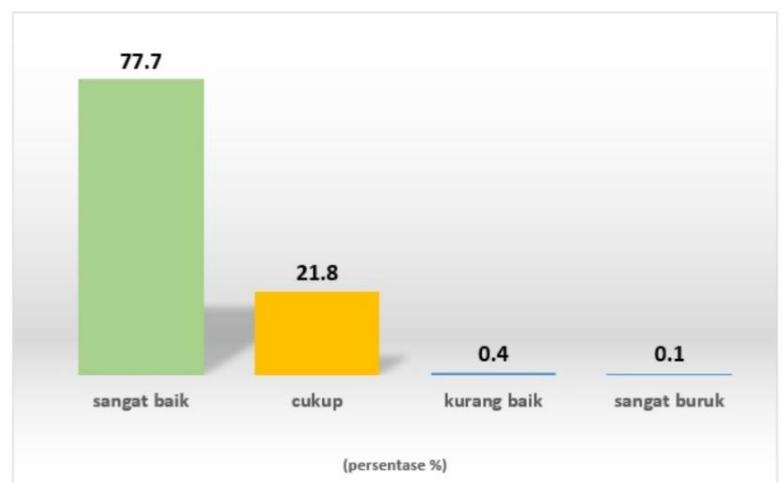

Diagram 2. ${ }^{31}$ Persepsi Konsumen terhadap Layanan Transportasi Online. Persepsi berdasarkan data diatas memperlihatkan sebuah kekuatan baru itu lahir dan mulai mengusik keadaan ideal yang telah dinikmati sebelumnya oleh komunitas yang telah menguasai dan menjalankan sistem transportasi umum. Kekuatan komunitas baru itu membawa konsep layanan yang seharusnya ditingkatkan secara berkesinambungan oleh penyelenggara sistem transportasi umum konvensional, namun komunitas baru rupanya sukses dalam mengkolaborasikan pelayanan tersebut dengan sentuhan teknologi informasi yang sedang digandrungi dewasa ini.

Motamorfosa $^{32}$ angkutan umum masyarakat telah melahirkan bentrok antar driver dengan supir, realitasnya terdapat banyak kisah yang hingga kini

31 Op.Cit

32 Aan Aswari, Andika Prawira Buana, Farah Syah Rezah, Op, Cit menghiasi gambaran chaos $^{33}$ sejak keberadaan teknologi dalam transportasi umum. Masyarakat yang terlebih dahulu menguasai usaha transportasi umum konvensional sulit menerima kenyataan ${ }^{34}$ akan kehadiran teknologi yang kemudian banyak dimanfaatkan oleh berbagai kalangan komunitas masyarakat digital native. ${ }^{35}$ Terlihat bahwa komunitas baru kemudian berupaya menggeser sistem yang telah berjalan sejak dahulu sehingga acapkali terjadi bentrok, padahal perlu untuk disadari oleh masyarakat bahwa era pemanfaatan teknologi ini meningkatkan kualitas pasar, namun efisiensi yang mendukung kualitas pasar dapat tereduksi karena adanya peraturan pemerintah yang berlebihan dan kurangnya kompetisi pasar. ${ }^{36}$

Bentrokan yang terjadi diprakarsai oleh dua kelompok, kelompok yang pertama adalah mereka dari kalangan komunitas transportasi umum konvensional, dan kedua berasal dari kalangan komunitas transportasi umum berbasis aplikasi. Kelompok pertama menyuarakan tentang legalitas sistem yang dijalankan oleh mereka yang memanfaatkan aplikasi, dan kelompok kedua menyuarakan tentang kelayakan mereka dalam melayani kepentingan umum yang harus terus berinovasi melalui kehadiran produk yang dapat dimanfaatkan oleh jumlah orang yang lebih banyak.

Legalitas tindakan yang timbul dari produk inovatif tersebut menjadi celah yang dianggap tidak pantas dijalankan oleh driver karena tidak memiliki pengaturan terkait

33 Sentuhan teknologi informasi dalam transportasi umum memberikan gambaran masalah dalam tataran empiris. Lihat: Faisal, (2014). Memahami hukum Progresif, Thafa Media, Yogyakarta. Hal, 19.

34 Manueke, Manuela; Tampi, Gustaaf Budi; Londa, Very. Persepsi Masyarakat Tentang Jasa Transportasi Berbasis Aplikasi Online Di Kota Manado (Studi Kasus Di Pt. GoJek). Jurnal Administrasi Publik, 2018, 4.51.A

35 Masyarakat digital native adalah generasi yang lahir setelah tahun 1990an dan lahir bersama lahirnya era teknologi digital sehingga memiliki sebuah karakteristik berbeda dengan generasi sebelumnya dan senang memanfaatkan teknologi digital secara maksimal. Lihat: Maryani, Eri. "Peningkatan Kualitas Pelayanan Perpustakaan Untuk Digital Native Generation (Perspektif Perubahan Karakter Pemustaka di Era Digital)." PROSIDING KOMUNIKASI 1.1 (2017).

36 Spahn, Elizabeth. "Nobody gets hurt." Geo. J. Int'l L. 41 (2009): 861-1043 
pelaksanaannya, dimana tanggung jawabnya belum diatur dalam berbagai peraturan perundang-undangan secara utuh, sehingga selalu dijadikan alasan mengganggu jalannya sistem yang terlebih dahulu telah ada karena tidak berdasarkan hukum. Kerancuan yang timbul akibat pengaturan yang belum sempurna ini sering kali terjadi pada setiap produk inovatif yang terkesan berusaha menyingkirkan mereka yang telah menikmati manfaat sejak lama, meski sesungguhnya terdapat peran smart system pada transportasi umum, namun regulasi yang ada memang terkesan kurang tanggap untuk segera memperbaiki keadaan menjadi seimbang seperti layaknya transportasi konvensional telah jelas diatur tentang hak dan kewajiban yang mereka wajib laksanakan.

Kelayakan yang ditawarkan oleh model terbarukan memang sangat memiliki kelebihan yang dapat digunakan dibanding sebelumnya, sebagaimana sering disuarakan dalam aksi demonstrasi yang diprakarsai oleh komunitas pengguna transportasi umum berbasi aplikasi, namun hal tersebut dapat juga dijadikan sebuah ancaman bagi manusia-manusia moderen, diantaranya:

1. Membuat jurang pemisah antara kedua komunitas yang ada;

2. Melanggar ketentuan rambu-rambu;

3. Meningkatnya wanprestasi dalam berbagai aspek;

4. Melahirkan penyalahgunaan keilmuan yang diakomodir oleh penyelenggara agen elektronik. Keterjangkauan wilayah transportasi umum (aksesibilitas) ${ }^{37}$ seharusnya dapat secara penuh diraih melalui pengembagan, namun menjadi masalah dalam aksesibilitas ketika acapkali terdapat batasan dalam untuk memasuki wilayah trayek tertentu oleh pemanfaat transportasi umum berbasis aplikasi ketika memasuki wilayah yang dibatasi oleh pemanfaat transportasi umum konvensional, misalnya wilayah yang telah lama dimanfaatkan oleh komunitas ojek pangkalan. Pertikaian sering terjadi ketika driver yang

37 Aminah, S. Transportasi Publik dan Aksesibilitas Masyarakat Perkotaan. Jurnal Fisip, Universitas Airlangga, Surabaya. (2006) 31-45 dilengkapi dengan atribut tertentu ${ }^{38}$ sedang mengantarkan/telah mengantarkan penumpang ketempat yang dibatasi oleh mereka yang menganggap wilayah tersebut adalah wilayah komunitas yang menjalankan sistem konvensional. ${ }^{39}$ Terkait keterjangkauan disini dapat dilihat bahwa sesungguhnya keterjangkauan sistem inovatif itu malah membuat aksesibilitas semakin terbatas dibanding sebelumnya.

Sebuah wilayah fasilitas umum yang diadakan baik oleh pemerintah maupun pihak swasta juga menjadi sebuah wilayah yang diperebutkan untuk dikuasai oleh kedua komunitas yang sedang berseteru akibat sentuhan teknologi pada transportasi umum, misalnya wilayah bandara, terminal, mall, objek wisata dll. Hal ini memberikan gambaran bahwa sikap yang membentuk kewilayahan kekuasaan tertentu menjadikan salah satu komunitas merasa semakin terdesak, dan hanya terus berfikir demikian hingga melupakan esensi yang ingin digapai dari terbentuknya transportasi umum untuk melayani perpindahan masyarakat dalam kebutuhan sehari-harinya. Pemikiran demikian hanya membatasi ruang gerak komunitasnya sendiri dan berfokus pada mempertahankan wilayah kekuasaan, termasuk melupakan pelayanan optimal dari sebuah bentuk transportasi umum yang harus diberikan kepada masyarakat sebagai pengguna untuk memperluas wilayah jangkauan, dan pengembangan pola yang perlu ditingkatkan agar menjadikan komunitas ini lebih bersaing secara sehat melalui temuan-temuan yang inovatif dalam meraih minat penumpang melalui kualitas pelayanan, ${ }^{40}$ olehnya pola mempertahankan kewilayahan yang tak terjelaskan tersebut hanya diselesaikan dengan cara ilegal, eigenrichting dan/atau bahkan

\footnotetext{
$38 \quad$ Resa Esnir, (2016)

http: //www.hukumonline.com/berita/bacafoto/lt56f10 3ed5bcd9/pengemudi-ojek-online-dan-sopir-taksibentrok (diakses 8 Januari 2018)

39 Billiocta, Y, Padmasari, SI, https://www.merdeka.com/peristiwa/sopirkonvensional-di-makassar-tebar-ancaman-hingga-bakaratribut-ojek-online.html (diakses: 8 januari 2018)

40 Sangaji, Mamang Etta. Sopiah.(2013) Perilaku Konsumen; Pendekatan Praktis disertai Himpunan Jurnal Penelitian. Yogyakarta: Penerbit Andi. hal, 100
} 
memasuki wilayah hak orang lain tanpa izin (meretas sistem elektronik).

Produk teknologi ini merupakan contoh bahwa sesungguhnya terdapat kelemahan yang baru pula sebagai sebuah kegagalan bentuk produk anak manusia dalam pengembangannya memenuhi kebutuhan manusia dewasa ini. Rupanya hal ini memperjelas bahwa kelemahan pada sistem konvensional yang dianggap perlu diperbarui sehingga dapat menyembuhkan luka malahan pada sistem baru terlihat membuka luka baru pula, dimana sesungguhnya diharapkan kegagalan tersebut seharusnya tidak dirasakan langsung, ketika peran produk hukum yang visioner dan produk teknologi yang berkualitas itu hadir mengakomodir kepentingan masyarakat. Gambaran tersebut memperlihatkan sekedar bentuk inovasi yang diterapkan tanpa pertimbangan panjang, baik pada produk hukum yang selalu diharapkan tertatih-tatih mengikuti perubahan zaman, maupun produk manusia yang diterapkan tetapi memiliki tingkat kemudaratan yang cukup tinggi. Menjadi sebuah pertanyaan penulis, apakah produk hasil kajian ilmu pengetahuan kini hanya dibentuk tanpa mempertimbangkan sisi humanis didalam pembentukannya dengan mengabaikan kajian hukum secara utuh.

Sisi lain menggambarkan bahwa terdapat masalah pula dalam rekruitmen driver sebagai manusia harapan yang membawa kebaikan dalam pelaksanaan produk teknologi transportasi online ini, masyarakat informasi sangat diperlukan perannya untuk menyempurnakan pemanfaatan teknologi namun acapkali tidak dibarengi dengan peningkatan mutu yang terlihat dalam realitasnya berkendara. Meskipun diketahui tidak lagi menggunakan kecepatan tinggi dan saling berebutan mencari penumpang, namun tetap saja tidak mengindahi peraturan lalu lintas, yang mana diketahui bahwa salah satu penyebab timbulnya kecelakaan adalah tidak mengindahi peraturan lalu lintas. Masih saja sering terlihat adanya kesamaan prilaku driver dengan supir yang seharusnya terdapat perbedaan signifikan, hal ini memperlihatkan teknologi tidak didukung dengan sumber daya manusia yang diharapkan dapat menjalankannya dengan kualitas maksimal, untuk menjawab masalah kegagalan kegunaannya, tentu masalah ini dapat dikaji lebih mendalam dengan teori efektivitas hukum yang merupakan faktor-faktor penghambat atau pendorong yang menunjukkan kepatuhan terhadap hukum. ${ }^{41}$

Peraturan yang ada telah mengakomodir pemanfaatan teknologi pada transportasi umum ini, ${ }^{42}$ namun kegagalan demi kegagalan terus mengiringi produk terbarukan ini oleh bisnis praktis yang diselenggarakan oleh pemilik modal usaha dalam upayanya untuk menghindari kepentingannya dihalangi oleh peraturan melalui upaya suap, hal itu membuat pejabat pemerintah yang menerima suap membalas budi dengan mengurangi hambatan transportasi umum konvensional yang hadir dari peraturan tersebut melalui kewenangannya untuk membuat kebijaksanaan atau menjaga eksistensi dengan membangun kekuatan melalui pembentukan peraturan yang ketat dan prosedur yang berbelit-belit. Upaya suap ini bagaikan melenyapkan sampah yang membawa masalah kesehatan dalam kehidupan manusia dan tak ingin melihatnya lagi.

Keadaan yang tidak kalah ironisnya ketika masyarakat berasumsi bahwa potensi pekerjaan dapat dijalankan dengan mudah dan membuka peluang pekerjaan besar-besaran terlihat sangat menjanjikan, dan dianggap dapat memperbaiki tingkat kesejahteraan, ${ }^{43}$ namun sejak aplikasi ini dimanfaatkan terdapat banyak wanprestasi terjadi diberbagai sektor lembaga pembiayaan, meningkatnya penyitaan kendaraan cicilan, dan prilaku ketidak taatan terhadap peraturan lalu lintas hingga ancaman keselamatan

41 Marzuki, M. (2017). Penelitian Hukum: Edisi Revisi. Prenada Media, Jakarta. Hal, 10.

42 Permenhub Nomor 108 Tahun 2017 tentang Penyelenggaraan Angkutan orang dengan Kendaraan Bermotor Umum Tidak Dalam Trayek.

43 Pranoto, Agung Hadi. Siasat Manipulatif Dalam Kompetisi Pengemudi Gojek di Kota Surabaya. Diss. Universitas Airlangga, 2017. 
jiwa ${ }^{44}$ memperlihatkan buruknya sistem yang dianggap menjanjikan tersebut, sehingga akhirnya memaksa masyarakat yang memiliki tingkat pemahaman keilmuan yang lebih tinggi untuk mencari cara untuk tetap berprestasi dengan lembaga pembiayaan dengan pola yang variatif, secara umum baik dengan pola legal maupun sebaliknya. Sekian banyak kegagalan yang terjadi, harapan masyarakat untuk menggapai cita-citanya sulit terwujud dan temuan ini dalam sebuah produk baru berteknologi ini pada akhirnya dianggap bukan sebuah solusi yang terbaik dalam mewujudkan tujuan pemerintah dalam mendorong peningkatan kesejahteraan masyarakatnya.

Ancaman terlihat semakin terbuka besar dan membuat luka dalam produk terbarukan ketika persoalan pada transportasi umum konvensional sudah hampir terselesaikan, namun ketika hadirnya produk baru malah membuka peluang besar bagi sebagian orang untuk menyalahgunakan keilmuannya dalam meraih keuntungan yang besar. Kini, orderan fiktif menghiasi perjalanan penyempurnaan transportasi umum, seolah-olah telah melakukan kewajibannya namun menuntut haknya secara sempurna, kondisi ini secara nyata mengabaikan orientasi terhadap pelanggan untuk mengembangkan hubungan jangka panjangnya dalam bentuk eksistensi keberadaan produk transportasi umum berteknologi yang diharapkan mampu memberikan pelayanan maksimal saat ini pada masyarakat yang dapat mempertahankan laba secara berkelanjutan. ${ }^{45}$ Data tersajikan bagi pemerintah memperlihatkan adanya peningkatan daya kerja masyarakat, namun data tersebut merupakan data fiktif dan sesungguhnya masyarakat dalam keadaan stagnan. Hal ini berasal dari informasi fiktif yang disajikan oleh

44 Doly, Denico. Penegakan Hukum Terhadap UndangUndang Nomor 22 Tahun 2009 Tentang Lalu Lintas Dan Angkutan Jalan: Tantangan Dan Prospek. Jurnal Kajian, (Pusat Pengkajian, Pengolahan Data Dan Informasi/P3di Sekretariat Jenderal Dpr Ri),2016, 20.3: 219-240.

45 Valenzuela, Leslier M., Jay P. Mulki, and Jorge Fernando Jaramillo. "Impact of customer orientation, inducements and ethics on loyalty to the firm: Customers' perspective." Journal of Business Ethics 93.2 (2010): 277-291. data elektronik fiktif, sehingga berpotensi melahirkan kebijakan yang tidak tepat sasaran.

Meski berbicara konsekuensi dari sebuah bentuk perubahan, namun hal ini tidak dapat dibiarkan terus berlanjut karena hukum dipercaya selalu dapat memberikan kekuatan dalam menyelesaikan persoalan yang timbul, dan sebagai sarana pendorong untuk mewujudkan cita hukum masyarakat. ${ }^{46}$ Jika sejak dulu terdapat cerita fiksi bahwa lilin dijadikan sumber informasi untuk dapat tetap eksis dalam melakukan perbuatan mencuri harta sebagai hak orang lain, maka seharusnya dapat dijadikan inspirasi untuk mengakomodir masalah menjaga koneksi internet untuk dapat menghasilkan tingkat kesejahteraan dengan cara ilegal, yaitu melakukan orderan fiktif. Orderan fiktif dapat merugikan banyak pihak, sebagaimana dijelaskan sebelumnya bahwa dapat berdampak pada penentuan kebijakan pemerintah yang tidak tepat sasaran, juga hal ini dapat dijadikan kebiasaan oleh masyarakat untuk terus melakukan perbuatan yang tidak terpuji terhadap hal-hal yang baru dari hasil kolaborasi teknologi informasi dan produk konvensional. Cukuplah Indonesia dimata dunia telah mendapatkan status black list dalam perdagangan dunia melalui transaksi online menjelang tahu 2000an, dimana penyalahgunaan kartu kredit untuk berbelanja dapat digunakan orang lain yang tidak memiliki hak. Pengalaman tersebut dapat dijadikan acuan untuk mengantisipasi adanya perbuatan melawan hukum baru pada produk baru yang lahir diera pemanfaatan teknologi informasi secara maksimal.

\section{Conclusion}

Evolusi kondisi kearah yang lebih baik telah diprakarsai oleh tujuan hukum acapkali dibarengi dengan evolusi ancaman untuk tetap berupaya mempertahankan kegagalan dalam hukum untuk mencapai tujuan hukum. Melalui upaya melahirkan gambaran kongkrit dari tujuan hukum dalam penyelenggaraan sistem

\footnotetext{
46 Nainggolan, J. (2015). Energi hukum sebagai faktor pendorong efektivitas hukum. Refika Aditama, Bandung, hal, 170
} 
transportasi umum online, maka sentuhan teknologi berupa produk inovatif itu telah melahirkan banyak bentuk pelayanan dari aksesibilitas yang semakin meningkat, sehingga informasi yang lancar dapat mempengaruhi pengambilan keputusan/tindakan yang tepat untuk barbagai kebutuhan yang diharapkan manusia, secara general dapat dikatakan bahwa sungguh teknologi informasi memberikan banyak kemudahan bagi hukum dalam mewujudkan tujuannya pada inovasi transportasi umum ini sehingga menjadi pengobat luka yang lama tak sembuh dari kegagalan produk sebelumnya, akibat keterbatasannya yang sesungguhnya dikonstruksi pula oleh manusia itu sendiri. Kini, kegagalan akibat keterbatasan terdahulu dapat disembuhkan dengan sentuhan teknologi informasi sebagai hasil karya manusia dan dirasakan oleh mayoritas masyarakat, namun sesungguhnya dapat diprediksi bahwa kedepannya akan ditemukan pula keterbatasan hukum dan produk inovatif ini ketika teknologi yang ada kini mulai menjadi usang.

Jika kini peningkatan aksesibilitas diprakarsai oleh konsep borderless world, maka dalam prakteknya kini terjadi pelebaran jurang pemisah yang saling membatasi wilayah kekuasaan dalam mencari penumpang bagi kedua komunitas yang ada, yaitu komunitas konvensional dan komunitas baru yang memanfaatkan produk teknologi, rupanya borderless world hingga kini masih saja belum dapat diterima oleh semua kalangan yang menggunakan perangkat teknologi dalam kesehariannya.

\section{Suggestion}

Transportasi umum konvensional yang seharusnya dilekatkan sistem yang dijalankan oleh alat yang digunakan oleh transportasi umum berbasis aplikasi ini secara maksimal, sehingga tidak menimbulkan sebuah komunitas baru yang dapat membuat sebuah komunitas lama terasa terusik dengan keberadaan sistem yang telah lama dijalankan. Hal ini mengisyaratkan agar kedua komunitas ini dapat berkolaborasi dengan baik sehingga tidak perlu membuat aturan yang secara tegas memisahkan keduanya, sehingga tidak lagi terdapat kegagalan baru yang terlihat sebagai luka lama yang tak tersembuhkan ketika penyempurnaan itu dilakukan dalam bentuk evolusi pada transportasi umum konvensional.

\section{REFERENCES}

Amajida, Fania Darma. Kreativitas Digital Dalam Masyarakat Risiko Perkotaan: Studi Tentang Ojek Online “Go-Jek" Di Jakarta. Informasi, 2014, 46.1: 115-128. Http://Dx.Doi.Org/10.21831/Informasi.V $46 \mathrm{i} 1.9657$

Aminah, S. Transportasi Publik dan Aksesibilitas Masyarakat Perkotaan. Jurnal Fisip, Universitas Airlangga, Surabaya. (2006) 31-45

Anindhita, Wiratri, Melisa Arisanty, And Devie Rahmawati. "Analisis Penerapan Teknologi Komunikasi Tepat Guna Pada Bisnis Transportasi Ojek Online (Studi Pada Bisnis Gojek Dan Grab Bike Dalam Penggunaan Teknologi Komuniasi Tepat Guna Untuk Mengembangkan Bisnis Transportasi)." Prosiding Seminar Nasional Indocompac. 2016.

Asnawi, M. N. (2013). Hukum Pembuktian Perkara Perdata Di Indonesia. UII Press, Yogyakarta.

Aswari, Aan, et al. Legal Security On Cellphone Trading Through Electronic Media In Indonesia. Jurnal Dinamika Hukum, 2017, 17.2: 181-187. Doi: 10.20884/1.jdh.2017.17.2.800

Aswari, Aan; Buana, Andika Prawira; Rezah, Farah Syah. Harmonisasi Hukum Hak untuk Dilupakan bagi Koran Digital terhadap Calon Mahasiswa di Makassar. Kanun: Jurnal Ilmu Hukum, Universitas Syiah Kuala, Banda Aceh. 2018, 20.1: 39-62. Doi: 10.24815 /kanun.v20i1.9828

Bakar, Noor Rahamah Haji Abu, et al. Masa Kerja Fleksibel dalam Sektor Formal di Bandar: Mengimbangi Kerjaya dan Tanggungjawab Keluarga (Flexible Working Hours in the Urban Formal Sector: Balancing Career and Family Responsibilities). Akademika, Universiti Kebangsaan Malaysia, 2013, 83.1.

Budhijanto, D. (2010). Hukum telekomunikasi, penyiaran, dan teknologi informasi: regulasi dan konvergensi. Refika Aditama, Bandung.

Doly, Denico. Penegakan Hukum Terhadap Undang-Undang Nomor 22 Tahun 2009 
Tentang Lalu Lintas Dan Angkutan Jalan: Tantangan Dan Prospek. Jurnal Kajian, (Pusat Pengkajian, Pengolahan Data Dan Informasi/P3di Sekretariat Jenderal Dpr Ri),2016, 20.3: 219-240.

Faisal, Faisal, (2014). Memahami hukum Progresif, Thafa Media, Yogyakarta.

Fidiyani, Rini, Dewi Sulistianingsih, and Pujiono Pujiono. "Law and Ethics of Communication in Social Media." Jurnal Dinamika Hukum 17.3 (2017): 258-265.

Hadjon, P. M., \& Djatmiati, T. S. (2005). Argumentasi hukum. Penerbit Gajah Mada University Press, Yogyakarta. Hal, 29.

Jazuli, Ahmad. Penegakan Hukum Penataan Ruang Dalam Rangka Mewujudkan Pembangunan Berkelanjutan. Jurnal Rechts Vinding: Media Pembinaan Hukum Nasional, 2017, 6.2: 263-282.

Makarim, Edmon, et al. Pengantar Hukum Telematika. Raja Grafindo. Jakarta, 2005.

Manueke, Manuela; Tampi, Gustaaf Budi; Londa, Very. Persepsi Masyarakat Tentang Jasa Transportasi Berbasis Aplikasi Online Di Kota Manado (Studi Kasus Di Pt. Go-Jek). Jurnal Administrasi Publik, 2018, 4.51.

Maryani, Eri. "Peningkatan Kualitas Pelayanan Perpustakaan Untuk Digital Native Generation (Perspektif Perubahan Karakter Pemustaka di Era Digital)." PROSIDING KOMUNIKASI 1.1 (2017).

Marzuki, M. (2017). Penelitian Hukum: Edisi Revisi. Prenada Media, Jakarta.

Maulidi, Maulidi. Paradigma Progresif dan Maqashid Syariah: Manhaj Baru Menemukan Hukum Responsif. AsySyir'ah Jurnal Ilmu Syari'ah dan Hukum, 2015, 49.2: 251-264. DOI: http: / /dx.doi.org/10.14421/asysyir'ah.2015.\%25x

Manueke, Manuela; Tampi, Gustaaf Budi; Londa, Very. Persepsi Masyarakat Tentang Jasa Transportasi Berbasis
Aplikasi Online Di Kota Manado (Studi Kasus Di Pt. Go-Jek). Jurnal Administrasi Publik, 2018, 4.51.A

Nainggolan, J. (2015). Energi hukum sebagai faktor pendorong efektivitas hukum. Refika Aditama, Bandung.

Nitisusastro, M. (2012). Perilaku Konsumen dalam Perspektif Kewirausahaan. Alfabeta, Bandung.

Pranoto, Agung Hadi. Siasat Manipulatif Dalam Kompetisi Pengemudi Gojek di Kota Surabaya. Diss. Universitas Airlangga, 2017.

Pratama, Geistiar Yoga, Et Al. Perlindungan Hukum Terhadap Data Pribadi Pengguna Jasa Transportasi Online Dari Tindakan Penyalahgunaan Pihak Penyedia Jasa Berdasarkan Undang-Undang Nomor 8 Tahun 1999 Tentang Perlindungan Konsumen. Diponegoro Law Journal, 2016, 5.3: 1-19.

Rahayu, Flourensia Sapty. Cyberbullying Sebagai Dampak Negatif Penggunaan Teknologi Informasi. Journal of Information Systems, 2012, 8.1: 22-31. Doi: Https://Doi.Org/10.21609/Jsi.V8i1.321

Sangaji, Mamang Etta. Sopiah.(2013) Perilaku Konsumen; Pendekatan Praktis disertai Himpunan Jurnal Penelitian, Penerbit Andi. Yogyakarta.

Sari, Ratna Kumala, et al. Pertanggungjawaban Pidana Korporasi Gojek Atas Tindak Pidana Kecelakaan Lalu Lintas Oleh Pelaku Driver Ojek Online Di Yogyakarta. Skripsi, Universitas Islam Indonesia, Yogyakarta. 2018.

Spahn, Elizabeth. "Nobody gets hurt." Geo. J. Int'l L. 41 (2009): 861-1043.

Qamar, Nurul; Mustamin, Hikmawati; Aswari, Aan. Local Wisdom Culture Of Bugis Makassar In Legal Perspective. Adri International Journal Of Law And Social Science, 2017, 1.1: 35-41.

Qamar, Nurul Dkk, 2018. Menguak Nilai Kearifan Lokal Bugis Makassar, Perspektif Hukum Dan Pemerintahan. Cv.Social Politic Genius (Sign), Makassar. 
Valenzuela, Leslier M., Jay P. Mulki, and Jorge Fernando Jaramillo. "Impact of customer orientation, inducements and ethics on loyalty to the firm: Customers' perspective." Journal of Business Ethics 93.2 (2010): 277-291.

\section{Perundang-Undangan}

Kitab Undang-Undang Hukum perdata Buku III tentang Perikatan

Undang-Undang Nomor 22 Tahun 2009 Tentang Lalu Lintas Dan Angkutan Jalan

Undang-Undang Nomor 8 Tahun 1999 tentang

Perlindungan Konsumen

Undang-Undang Nomor 19 Tahun 2016, Perubahan atas Undang-Undang Nomor 11 Tahun 2008 tentang Informasi dan Transaksi Elektronik

Peraturan pemerintah Republik Indonesia Nomor 82 tahun 2012 tentang Penyelenggaraan Sistem dan Transaksi Elektronik.

\section{Websites}

https://ylki.or.id/2017/07/warta-konsumentransportasi-online-kawan-atau-lawan/

(Diakses 14 Maret 2018)

Resa Esnir, (2016)

http://www.hukumonline.com/berita/bacafot o/lt56f103ed5bcd9/pengemudi-ojek-onlinedan-sopir-taksi-bentrok $\quad$ (diakses 8 Januari 2018)

Billiocta, Y, Padmasari, SI, (2017) https://www.merdeka.com/peristiwa/sopirkonvensional-di-makassar-tebar-ancamanhingga-bakar-atribut-ojek-online.html (diakses: 8 januari 2018)

Permenhub Nomor 108 Tahun 2017 tentang Penyelenggaraan Angkutan orang dengan Kendaraan Bermotor Umum Tidak Dalam Trayek.

https: / /metro.sindonews.com/read/1278361/1 70/raup-rp600-juta-dari-order-fiktif-tuyulgrab-dicokok-polisi-1517410196 (diakses, 27 Februari 2018)

https://www.grab.com/id/kodeetik/ (diakses 3 Maret 2018) 